九州大学学術情報リポジトリ

Kyushu University Institutional Repository

\title{
Ultrastructure of the Porose Areas and their Accessory Glands in Haemaphysalis Zongicornis (Acari: Ixodidae)
}

Kakuda, Hiroyuki

Zoological Laboratory, Faculty of Agriculture, Kyushu University

Mori, Takayuki

Zoological Laboratory, Faculty of Agriculture, Kyushu University

Shiraishi, Satoshi

Zoological Laboratory, Faculty of Agriculture, Kyushu University

https://doi.org/10.5109/24107

出版情報：九州大学大学院農学研究院紀要. 40 (1/2)，pp. 209-211，1995-12. Kyushu University バージョン：

権利関係 : 


\title{
Ultrastructure of the Porose Areas and their Accessory Glands in Haemaphysalis Zongicornis (Acari: Ixodidae)
}

\author{
Hiroyuki Kakuda, Takayuki Möri and Satoshi Shiraishi* \\ Zoological Laboratory, Faculty of Agriculture, Kyushu University 46-06, \\ Fukuoka 812-81, Japan \\ (Received July 31, 1995)
}

\begin{abstract}
The ultrastructure of the porose areas and their accessory glands was investigated in Haemaphysalislongicornis. The porose areas symmetrically located on the dorsal surface of the basis capituli are openings of their accessory glands. The cuticle of the basis capituli is penetrated by the duct, the mid-region of which has a valve-like structure. In the unfed stage the duct cells, secretory cells and sheath cells are present just below the cuticle. As feeding proceeds, duct cells and external sheath cells extend very long and their distal end reach the anterior idiosomal cavity. Abundant microtubules traversing the cytoplasm of duct cells and sheath cells may have a mechanical role maintaining endurance of the cells during extreme extension. Secretory cells hypertrophy during feeding and become a simple branched acinar gland consisting of 6-8 acini at the distal end of duct cells during oviposition. Rough endoplasmic reticulum, Golgi complexes, secretory granules undergoing exocytosis suggest that secretory cells have a protein-synthesis ability. Secretions discharged into the secretory canaliculi are released into the duct lumen and out from the pore of the porose areas. These presumably influence egg wax and/or hatching in natural environmental conditions under which deposited eggs are exposed.
\end{abstract}

\section{INTRODUCTION}

The porose areas located on the dorsal surface of the basis capituli are two groups of pores found only in ixodid female, and other families of Ixodoidea (Argasidae and Nuttalliellidae) lack them. They were originally described as sense organs (Samson, 1909; Nordenskiold, 1909, 1911; Falke, 1931; Schulze, 1942; Douglas, 1943). Later, they were clarified to be not sense organs, but the openings of the accessory glands, and secretions from them function as a lubricant for movement of Gene's organ (FeldmanMuhsam and Havivi, 1960; Feldman-Muhsam, 1963). However, Atkinson and Binnington (1973) stated that these secretions function as an anti-autoxidant of certain components in the egg wax and their chemical composition has been presumed by chemical analyses (Vermeulen et al., 1986). Ultrastructure of the accessory glands of the porose areas has been reported in detail in Boophilus microplus (Booth et al., 1984) and Rhipicephalus evertsi evertsi (Gothe et al., 1987), but no information on Haemaphysalis ticks. In the present study, ultrastructure of the porose areas and the accessory glands, and structural changes of the latter from the unfed to the ovipositing stage have been investigated in $H$. longicomis, and the functional role of secretions from the glands is discussed.

\footnotetext{
* To whom reprint requests should be adressed
} 


\section{MATERIALS AND METHODS}

Adult $H$. longicomis (bisexual strain) collected by dragging on pastures in Kuju Highland, Oita Prefecture, were fed on ears of laboratory rabbits. Engorged females were maintained in a dark incubator at constant temperature and humidity $\left(30^{\circ} \mathrm{C}, 90 \% \mathrm{RH}\right)$. Unfed, feeding (5 days after attachment) and ovipositing (1 day after the onset of oviposition) females were used. For surface structural observation in the scanning electron microscope, the capitulum in the unfed stage was dehydrated in an ethanol series. The dried specimens were gold-coated and examined in an Hitachi-Akashi MSM-9 scanning electron microscope. For electron microscopy, the anterior part in the abovementioned stages of females were fixed for 3 hours with cold 3\% glutaraldehyde in sodium cacodylate buffer ( $\mathrm{pH} 7.2$ ), and then washed thoroughly in the same buffer. The tissues were postfixed for 3 hours with $1 \% \mathrm{OsO}_{4}$ in the same buffer, dehydrated in an ethanol series, and embedded in epoxy resin. Thin sections $(-60 \mathrm{~nm})$ were cut on a Porter-Blum MT-1 microtome, using a glass knife, and doubly stained with uranyl and lead acetate before examination in an Hitachi H-600A electron microscope. Semithin sections $(\sim 1.5 \mu \mathrm{m})$ for light microscopy were stained with toluidine blue.

\section{RESULTS}

\section{Porose areas}

The porose areas of H.longicomis are shown as two circles symmetrically located on the dorsal surface of the basis capituli (Fig. la). In each circle many pores with about 3 $\mu \mathrm{m}$ in diameter are irregularly arranged like a riddle (Fig. lb). The number of pores is about the same in both right and left circles but it ranges 50-70 with individual variations. The valve-like structure in the mid-region of the duct penetrating the thick cuticle separates the lumen consisting of the duct cells from the extraintegumental space (Fig. lc). In sagittal section of the duct, it shows a unique shape like an orchid flower (Fig. 2). The region above the valve-like structure is the cuticular duct lined with the epicuticle which continues along the body surface. However, duct cells form the cellular duct beneath the valve-like structure, and its distal part extends to the haemocoel of the basis capituli where secretory cells are present. Sheath cells are interposed between the duct cell and the procuticle of the basis capituli (Fig. 3). Microtubule-rich, electron-lucent duct cells extend downward during feeding, and the lumen of the duct is lined with sparse microvilli (Fig. 3). During oviposition, this long cellular duct (length $\sim 1 \mathrm{~mm}$ ) surrounded by sheath cells associates with each pore of the porose areas.

\section{Accessory glands}

In the unfed stage, the small accessory gland beneath the dorsal cuticle of the basis capituli consists of duct cells surrounded by sheath cells and some undeveloped secretory cells without lumen (Fig. 4a). In the junctional region between the duct cell and the secretory cell, they digitate each other and indicate a unique shape like the mandibles of a stag beetle with zonula adherens and septate junctions (Fig. 4b). The secretory cell contains heterochromatin-rich nucleus, mitochondria, free ribosomes and granular 


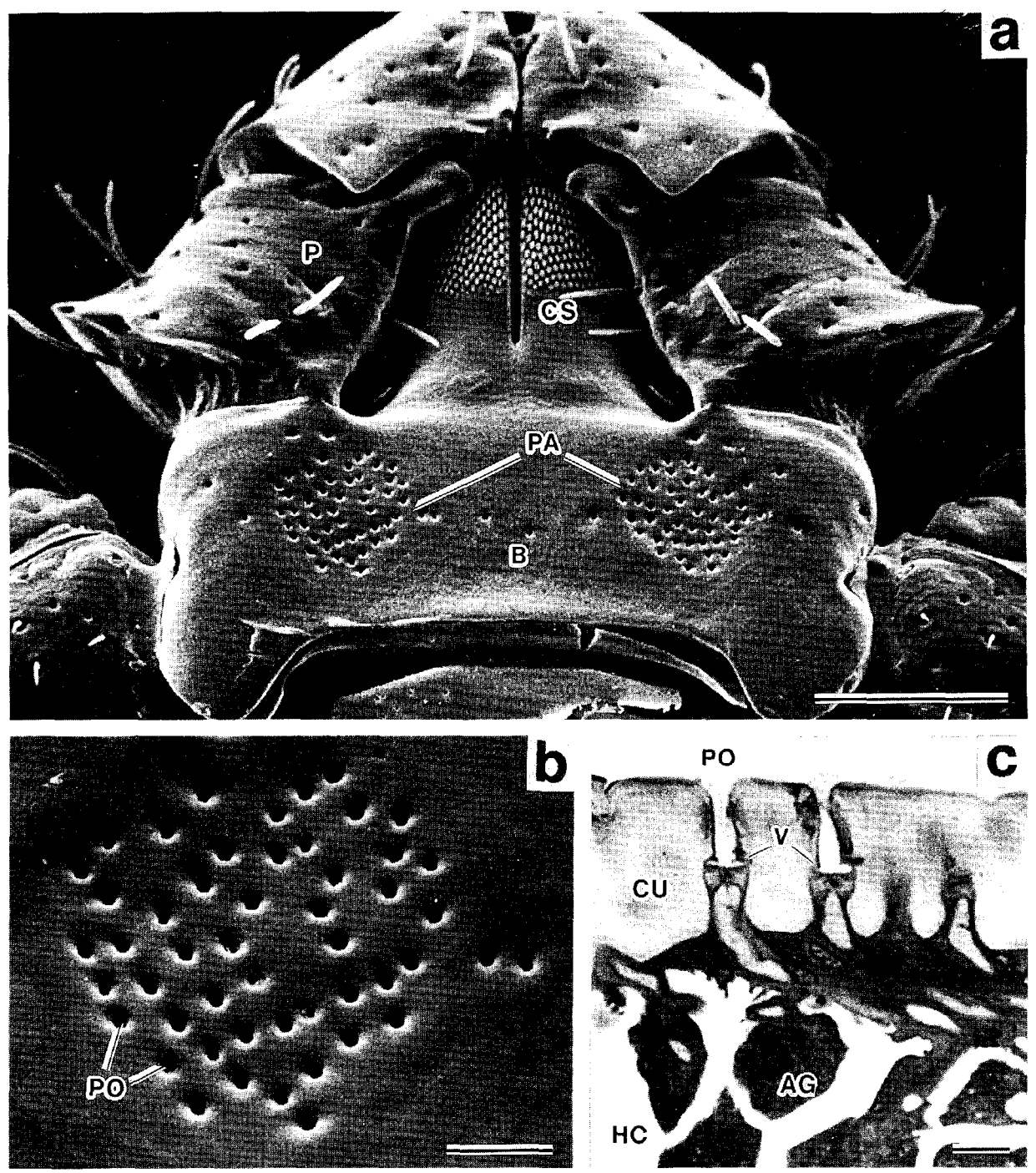

Fig. 1. Micrographs of the unfed female Haemaphysalislongicornis. a: Scanning electron micrograph of the capitulum. Two circles of the porose areas (PA) are symmetrically located on the dorsal surface of the basis capituli (B). b: Magnified view of the porose area showing the irregularly arranged pores (PO) like a riddle. c: Light micrograph of parasagittal section through the porose area showing the ducts penetrating the thick cuticle (CU) of the basis capituli and the accessory glands (AG) beneath the cuticle. Each duct has a valve-like structure (V) in the mid-region. CS, cheliceral sheath; HC, haemocoel; P, palp. Scale bars = $100 \mu \mathrm{m}$ (a), $20 \mu \mathrm{m}$ (b), $10 \mu \mathrm{m}$ (c). 


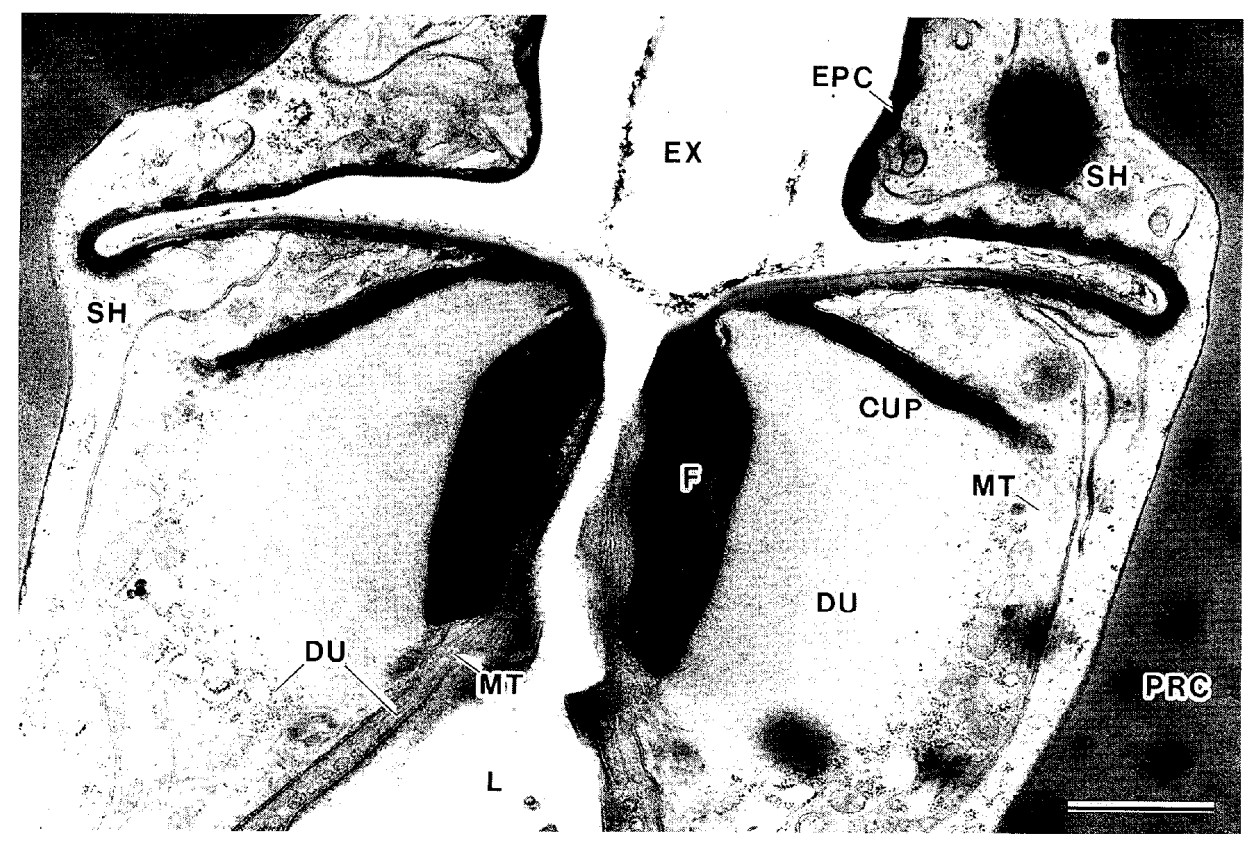

Fig. 2. Electron micrograph of sagittal section of the duct penetrating the procuticle (PRC) of the basis capituli in the unfed stage. The valve-like structure separates the lumen (L) of duct cells (DU) from extraintegumental space (EX). It consists of the cuticular projection (CUP) and the flap-like structure (F) which enable it to close circularly. Microtubules (MT) extend downward from these cuticular structures embedded in the duct cells. EPC, epicuticle; SH, sheath cell. Scale bar $=1 \mu \mathrm{m}$.

structures, and its junctional region with the duct cell projects microvilli. The small lumen formed by duct cells is filled with amorphous material (Fig. 4b).

On the 5th day after attachment, slight increase in volume of accessory glands and extension of duct cells are observed, but the glands have been located yet in the haemocoel of the basis capituli. Secretory cells with granular structures become electrondense by increasing free ribosomes (Fig. 5a). Sheath cells surrounding the duct cells with open lumen in layers also extend in accordance with extension of duct cells (Fig. 3), contain numerous microtubules (Fig. 5b), and their cytoplasm penetrates into the duct cell (Fig. 5c).

During oviposition, secretory cells extremely increase in volume and become a simple branched acinar gland consisting of 6-8 acini (diam. -80 رm) (Fig. 6) associated with a pore of the porose areas via a long non-branched cellular duct. All acini are located in the anterior idiosomal cavity. Acini are joined each other by intercellular digitation and contain a large euchromatin-rich nucleus, rough endoplasmic reticulum, Golgi complexes, secretory granules and mitochondria (Fig. 7a). Secretory canaliculi are present in the acinus and their lumen communicate with the duct lumen. The lumenal surface of the canaliculi projects long, well-developed microvilli beneath which a large number of mitochondria accumulates (Fig. 7b). Secretions in the cytoplasm are discharged into the 


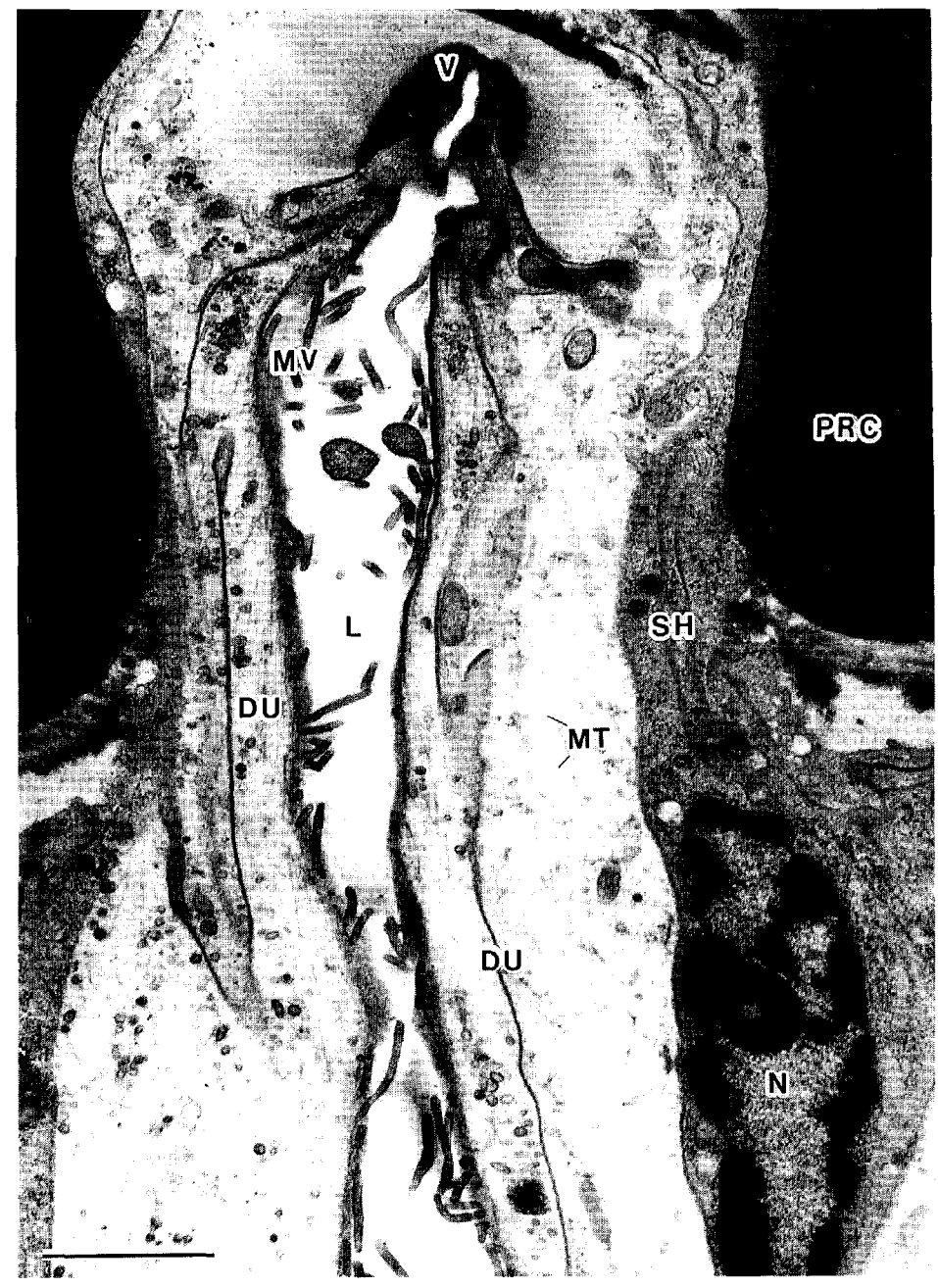

Fig. 3. Electron micrograph of the tissue just beneath the valve-like structure (V) on the 5th day after attachment, Electron-lucent duct cells (DU) enlarge during feeding. Lumenal surface projects long and widely spaced microvilli (MV). Abundant microtubules (MT) traverse the entire cell cytoplasm. Electron-dense sheath cells ( $\mathrm{SH}$ ) surrounding the duct cells also enlarge downward during enlargement of duct cells. L, lumen; N, nucleus; PRC, procuticle of the basis capituli. Scale bar $=2 \mu \mathrm{m}$. 

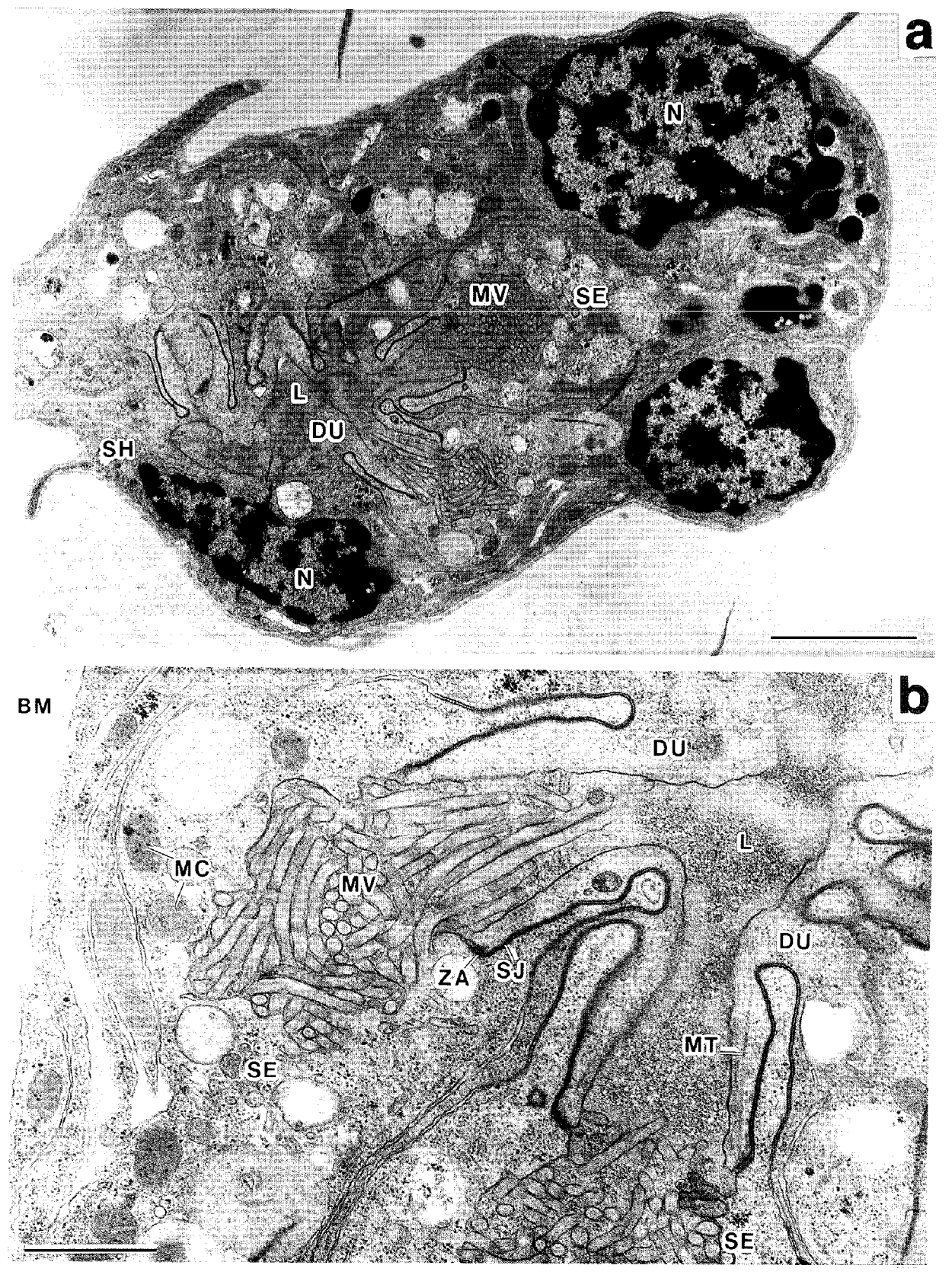

Fig. 4. Electron micrographs of the accessory glands in the unfed stage. a: Parasagittal section of an accessory gland showing distal secretory cells (SE) with microvilli (MV) and proximal duct cells (DU). Sheath cells (SH) surround the latter. b: Magnified view of the junctional region of secretory cells and the duct cell surrounding the lumen (L). Both cells digitate each other with cell processes like the mandibles of a stag beetle. BM, basement membrane; MC, mitochondrion; MT, microtubule; N, nucleus; SJ, septate junction; ZA, zonula adherens. Scale bars $=5 \mu \mathrm{m}(\mathrm{a}), 1 \mu \mathrm{m}(\mathrm{b})$. 


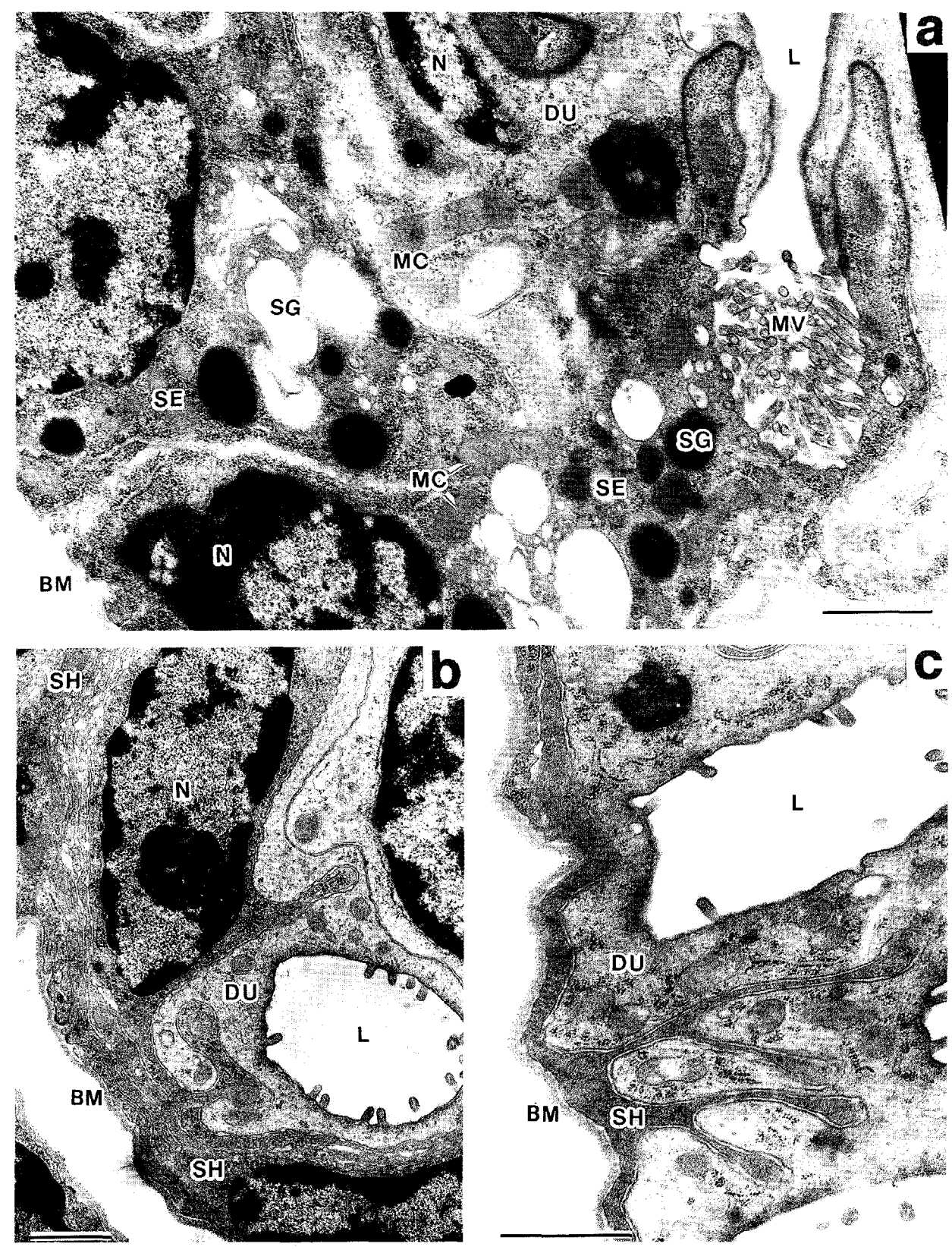

Fig. 5. Electron micrographs of the accessory glands on the 5th day after attachment. a: Secretory cells and duct cells. Secretory cells (SE) contain mitochondria (MC), numerous ribosomes and secretory granules (SG) in the cytoplasm. The lumen (L) of the duct cells (DU) opens. b: Sheath cells and duct cells. Sheath cells (SH) surround the duct cell (DLJ) in layers. c: Sheath cells and duct cells. The sheath cell $(\mathrm{SH})$ extends its cytoplasm as cell processes into the duct cell (DU). BM, basement membrane; MV, microvilli; N, nucleus. Scale bar $=1 \mathrm{pm}$. 


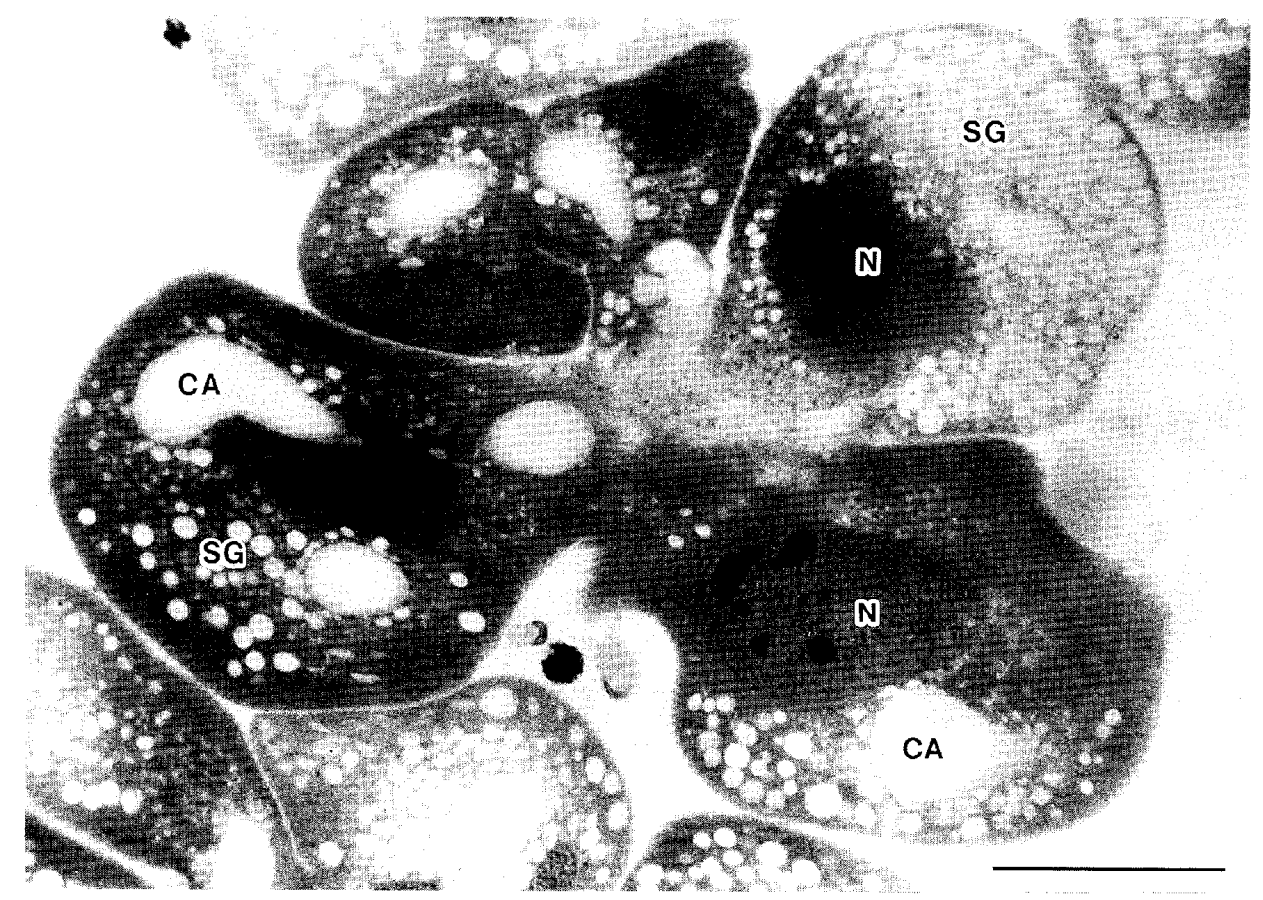

Fig. 6. Light micrograph of fully developed accessory glands during oviposition showing some acini joining together. Each acinus possesses secretory canaliculi (CA), numerous secretory granules $(\mathrm{SC}$,$) and a large nucleus (\mathrm{N})$ with increased euchromatin. Scale bar $=50 \mathrm{pm}$.

secretory canaliculi by exocytosis (Fig. 7c). The basal region of acini shows highly folded basal plasma membrane (Fig. 8a) and accumulation of glycogen particles (Fig. 8b). Secretions discharged into the canaliculi are released into the duct lumen via narrow part of the junction of the secretory and duct cells (Fig. 9), and they are released from pores of the porose areas. Schematic diagrams of the porose areas and their accessory glands during oviposition are shown in Fig. 10.

\section{DISCUSSION}

The porose areas and their accessory glands have a very similar structure to the dermal gland and its opening of ticks (El Shoura, 1988). The dermal gland is involved in formation of constituents of wax layer on the cuticle (Balashov, 1972; Amosova, 1983). However, the porose areas are present only in females, and Ixodes kopsteini exhibiting an unusual oviposition process in which larvae directly emerge from the female body cavity (ovoviviparity?), not from eggs, lacks the porose areas (Anastos et al., 1973); these two facts imply that the porose areas are involved in oviposition.

Duct cells forming the cellular duct beneath the valve-like structure of the porose areas correspond to the proximal cells of Rhipicephalus evertsi evertsi (Gothe et al., 


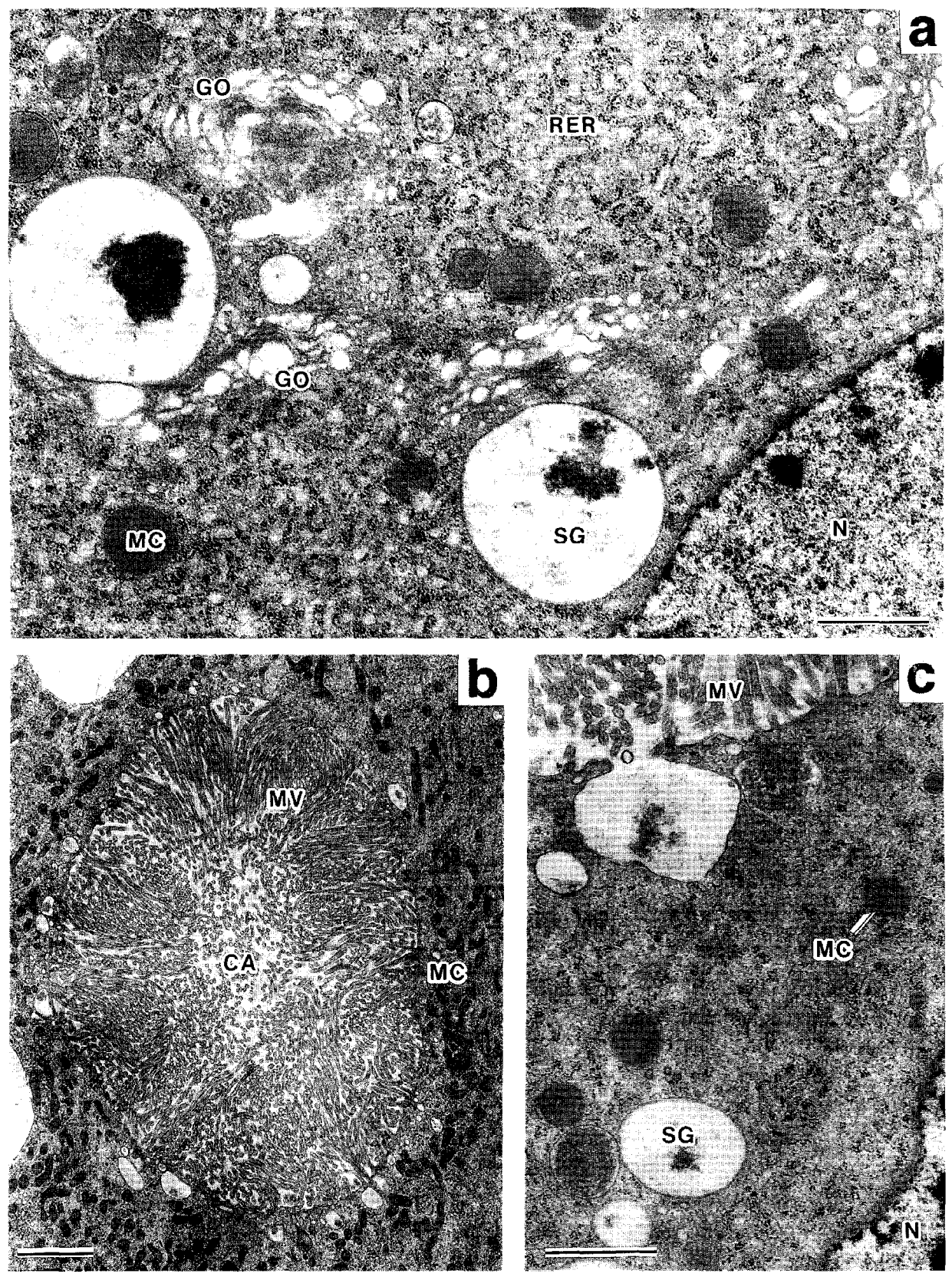

Fig. 7. Electron micrographs showing the acinar secretory cell of the accessory glands during oviposition, a: The cell contains non-cisternal rough endoplasmic reticulum (RER), Golgi complex (GO), secretory granules (SG) and mitochondria (MC). Note the large secretory granules in which most of contents being almost lost. b: The secretory canaliculus (CA). The free surface surrounding the canaliculus projects well-developed microvilli (MV) beneath of which a great number of mitochondria are present. c: The free surface showing a secretory granule undergoing exocytosis. $\mathrm{N}$, nucleus. Scale bars $=1 \mu \mathrm{m}(\mathrm{a}, \mathrm{c}), 2 \mathrm{pm}(\mathrm{b})$. 

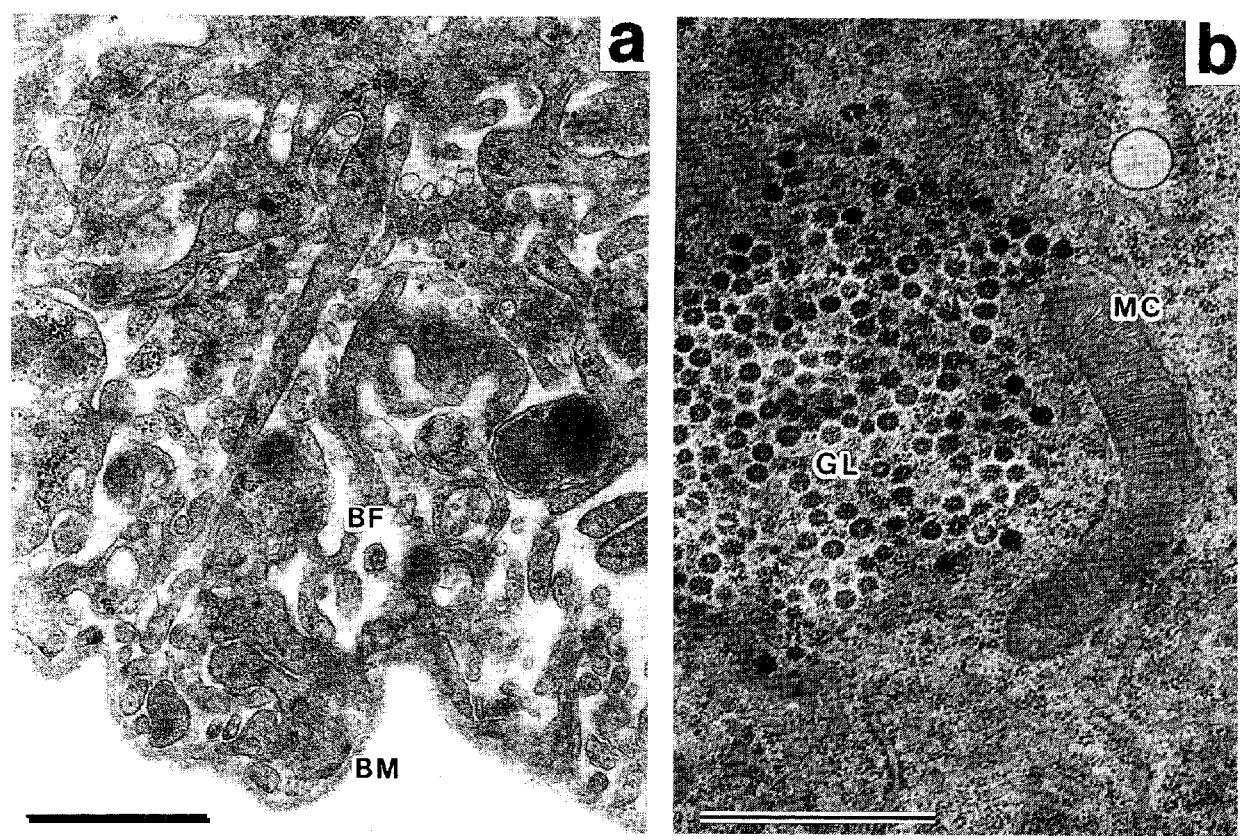

Fig. 8. Electron micrographs of the secretory cell as in Fig. 7. a: The basal region showing greatly folded basal plasma membrane $(\mathrm{BF})$. b: An area of cytoplasm containing a high concentration of glycogen in alpha particles (GL). BM, basement membrane; MC, mitochondrion. Scale bar $=1 \mathrm{pm}$.

1987). In the duct cells just beneath the valve, microtubules extending downward from cuticular structures (the flap-like structure and the cuticular projection) may have a mechanical role involved in closing and opening the valve. The cavity of the basis capituli is too small for distal accessory glands to develop remarkably during oviposition, so extension of the cellular duct up to the anterior idiosomal cavity enables the glands to develop fully. Abundant microtubules traversing the cytoplasm of duct cells presumably have a mechanical role to maintain endurance for the cells during extreme extension. Sparse microvilli projected into the duct lumen may be involved in a smooth transport of secretions. External sheath cells support the lengthened duct and their microtubules may support themselves during extension.

Secretory cells of accessory glands correspond to the distal cells of Rhipicephalus evertsi evertsi (Gothe et al., 1987). In Boophilus microplus a single acinus connects with each pore of the porose areas through a duct (Booth et al., 1984), but in $H$. longicomis 6-8 acini connected with each pore. Ultrastructure of secretory cells of acini is basically similar to that of $B$. microplus (Booth et al., 1984), indicating their proteinsynthesis ability. However, the fact that contents of most secretory granules in the cytoplasm are lost during making preparation may suggest that the granules contain lipid components. Highly folded basal plasma membrane of secretory cells indicates active absorption from the haemolymph. Absorbed material may be transformed into glycogen and stored as precursors of secretory products or as the energy resources utilized for 


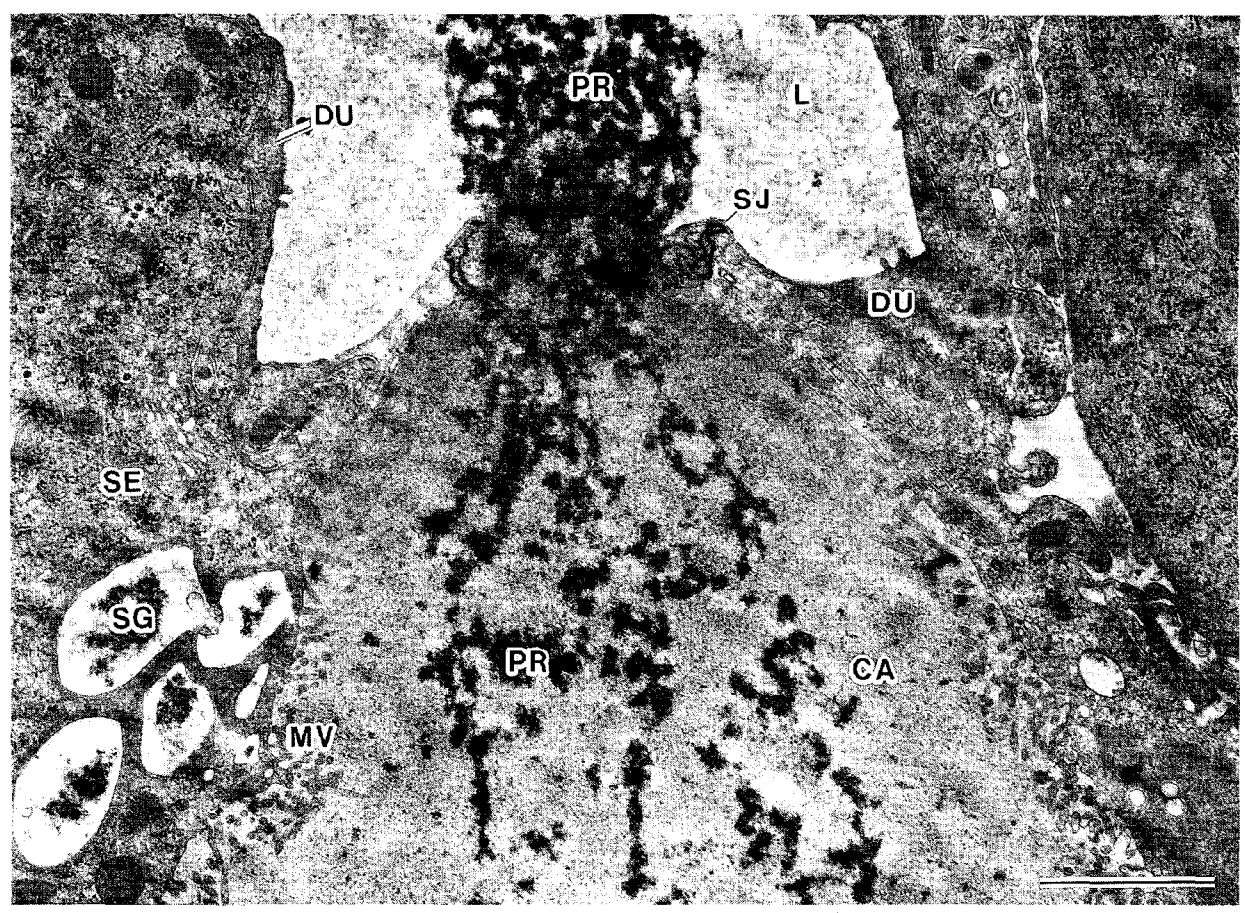

Fig. 9. Electron micrograph of the accessory glands as in Fig. 7. The junctional region of the acinar secretory cell (SE) and the duct cell (DU) showing electron-dense secretory products (PR) released from the canaliculus (CA) to the duct lumen (L). MV, microvilli; SG, secretory granule; SJ, septate junction. Scale bar $=2 \mu \mathrm{m}$.

synthesis and discharge of secretions. Secretory and absorbing activity of the cells during oviposition suggests that accessory glands of the porose areas are deeply involved in oviposition.

There is no significant difference in deposited egg number, hatching ratio (Atkinson and Binnington, 1973; Booth et al., 1984) and rate of oviposition (Gothe and Nadler, 1986) between females with blocked and unblocked (normal) porose areas. Thus, it is clear that secretions from the porose areas do not function as a lubricant for horns of Gene's organ repeating eversion and retraction during oviposition as described by Feldman-Muhsam and Havivi (1960) and Feldman-Muhsam (1963). Booth et al. (1984) and Gothe et al. (1987) have suspected that the secretions prevent the autoxidation of the A 2, 4, 6-triene steroids in the egg wax as described by Atkinson and Binnington (1973). However, the location of the porose areas suggests that secretions from them are applied to horns of Gene's organ moving repeatedly above there and have specific function as to the egg wax (Booth et al., 1984). HPLC and electrophoretic analyses of hexane, ethanol and butanol extracts of eggs obtained from ticks with blocked and unblocked porose areas demonstrated that secretions from the porose areas contain at least two hexane- and several ethanol- and butanol extractable components, i.e. some are of proteinaceous and others of an aliphatic and phenolic nature (Vermeulen et al., 1986). 


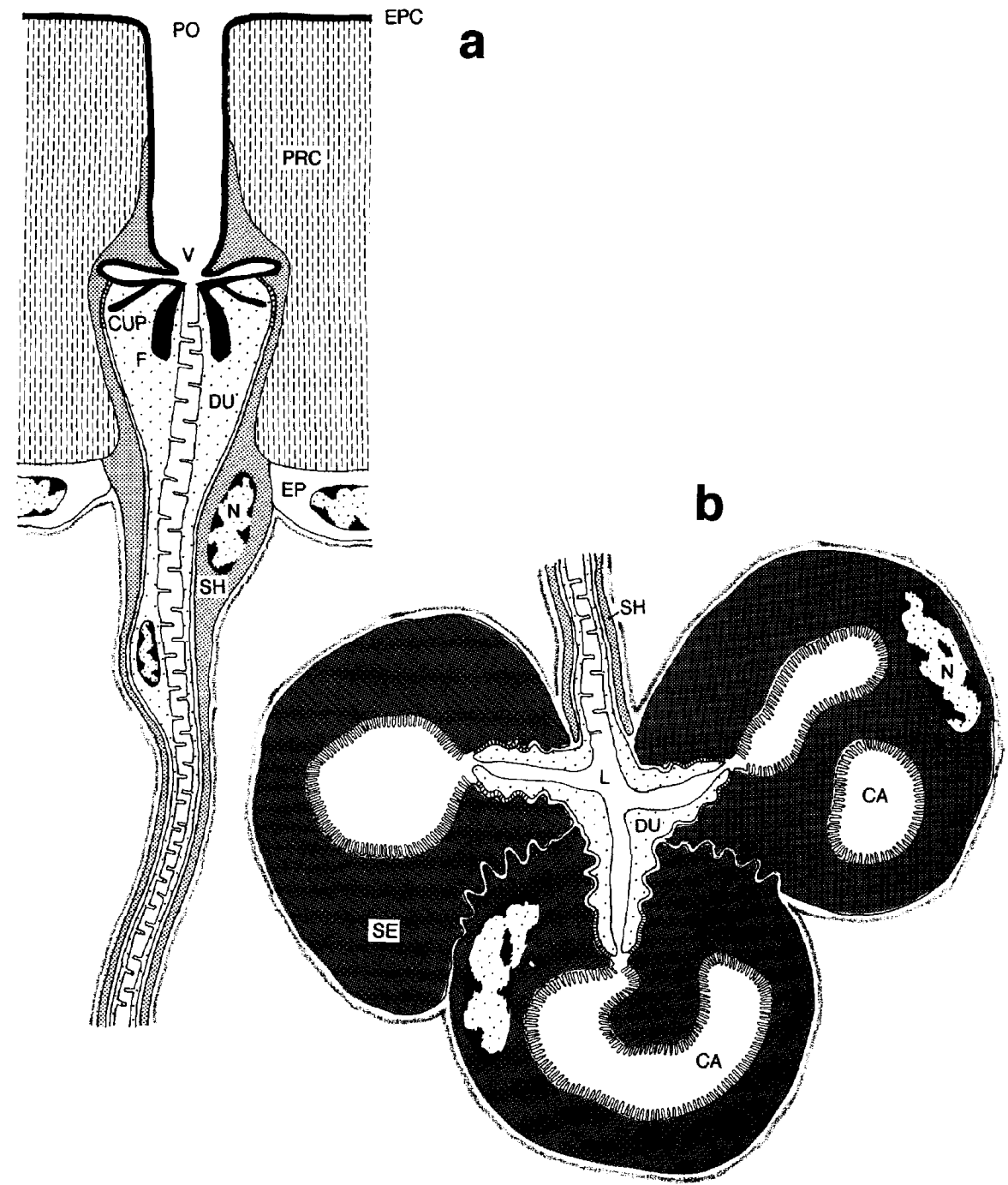

Fig. 10. Diagrammatic reconstruction of pores of the porose areas (a) and associated accessory glands (b) showing sagittal plane during oviposition. CA, secretory canaliculus; CUP, cuticular projection; DU, duct cell; EP, epithelial cell; EPC, epicuticle; F, flap-like structure; L, lumen; N, nucleus; PO, pore; PRC, procuticle; SE, secretory cell; $\mathrm{SH}$, sheath cell; V, valve-like structure.

Although function of the secretions has not yet been discovered under laboratory conditions, there must be the effect of the secretions on the egg wax and/or hatching under natural environmental condition. Difference of habitat between ixodids with the porose areas and argasids without ones could be a key to solve this question. 


\section{ACKNOWLEDGEMENTS}

We thank Professor R. Umezu and Dr. Y. Nakanishi (now of Kagoshima University), Kuju Agricultural Research Center of Kyushu University, for their help in collecting the ticks; Emeritus Professor S. Sumikawa and Assistant Professor S. Minobe, Fukuoka Women's University for permission to use a scanning electron microscope.

\section{REFERENCES}

Amosova, L. I. 1983 Integument. In "An Atlas of Ixodid Tick Ultrastructure", ed. by Yu. S. Balashov, Entomol. Soc. Am. Spec. Publ., pp. 23-58

Anastos, G., T. S. Kaufman and S. Kardarsan 1973 An unusual reproductive process in Ixodes kopsteini (Acarina: Ixodidae). Ann. Entomol.Soc. Am., 66: 483-484

Atkinson, P. W. and K. C. Binnington 1973 New evidence on the function of the porose areas of ixodid ticks. Experientia, 29: 799-800

Balashov, Yu. S. 1972 Bloodsucking ticks (Ixodoidea)-Vectors of diseases of man and animals. Transl. by 0. G. Strekalovsky, Misc. Publ.Entomol.Soc. Am, 8: 161-376

Booth, T. F., D. J. Beadle and R. J. Hart 1984 Ultrastructure of the accessory glands of Gene's organ in the cattle tick, Boophilus. Tissue Cell, 16: 589-599

Douglas, J. R. 1943 The internal anatomy of Dermacentorandersoni Stiles. Univ. Calif. Publ. Entomol., 7: 207-271

El Shoura, S. M. 1988 Ultrastructure of the nymphal integument in the camel tick Hyalomma (Hyalomma) dromedarii (Ixodoidea: Ixodidae). J.Morphol., 198: 1-13

Falke, H. 1931 Beiträge zur Lebengeschichte und zur postembryonalen Entwicklung von Ixodes ricinus L. Z.Morphol. Ökol. Tiere, 21: 567-607

Feldman-Muhsam, B. 1963 Function of the areae porosae of ixodid ticks. Nature,Lond., 197: 100

Feldman-Muhsam, B. and Y. Havivi 1960 Accessory glands of Gene's organ in ticks. Nature,Lond., 187: 964

Gothe, R. and Nadler, G. 1986 Zur funktionellen Bedeutung der Areae porosae weiblicher Rhipicephalus evertsievertsi Neumann, 1897. Dtsch.Tierärztl.Wochenschr., 93: 390-393

Gothe, R., E. Göbel and A. W. H. Neitz 1987 Histology and ultrastructure of the glands associated with the porose areas on the gnathosoma of Rhipicephalusevertsievertsi before and during oviposition. Exp. Appl. Acarol., 3: 255-265

Nordenskiold, E. 1909 Zur Anatomie und Histologie von Ixodesredumius. II. Zool. Jb., Abt. Anat., 27: 449-464

Nordenskiold, E. 1911 Zur Anatomie und Histologie von Ixodes reduvius. III. Zool. Jb., Abt. Anat., 32: 77-106

Samson, K. 1909 Zur Anatomie und Biologie von Ixodesricinus L. Z. wissen Zool, 93: 185-236

Schulze, P. 1942 Über die Hautsinnesorgane der Zecken, besonders über eine bisher unbekannte Art von Arthropoden-Sinnesorganen, die Krobylophoren. Z. Morphol. Okol.Tiere, 38: 379-419

Vermeulen, N. M. J., R. Gothe, A. C. Senekal and A. W. H. Neitz 1986 Investigations into the function and chemical compositions of the porose areas secretion of Rhipicephalusevertsievertsi during oviposition. Onderstepoort J.vet. Res., 53: 147-152 